Brit. F. industr. Med., 1968, 25, 220.

\title{
Carbon Disulphide Poisoning with Increased Ethereal Sulphate Excretion
}

\author{
L. S. DJERASSI and R. LUMBROSO 1 \\ From the Department of Industrial Medicine, Workers' Sick Fund, and the Analytical Laboratory, Haifa, Israel
}

A clear-cut change in urinary sulphate excretion has been found in a case of subacute carbon disulphide poisoning, the ethereal fraction being greatly increased to $\mathrm{I} \cdot 59 \mathrm{~g}$. $/ 1$., that is, $70 \%$ of the total urinary sulphate. Three weeks later the figure was still significantly abnormal: $1 \cdot 25 \mathrm{~g} . / 1$., i.e., $59 \cdot 6 \%$ of total sulphate excretion. The normal pattern of sulphate excretion was reached about six weeks after the last exposure: ethereal sulphate $0 \cdot 20$ g. $/ 1$. (8.7\%); inorganic sulphate $I \cdot 97$ g./1. $(85 \cdot 7 \%)$; neutral sulphur $0.13 \mathrm{~g} . / 1$.

\section{Case Report}

A 24-year-old member of an agricultural collective settlement was referred to our clinic as an urgent case on December 12, 1963 because of the progressive onset of defects in memory, symptoms of mental confusion, and disturbance of vision. It was reported that the patient had been exposed to the insecticide Calandrex on December 4 and 5, i.e., his last exposure had been seven days before his first examination in our department. Calandrex, ${ }^{2}$ a mixture of trichloroethylene $64 \%$, carbon tetrachloride $10 \%$, and carbon disulphide $26 \%$, is used in the periodic treatment of grain in silos. Safety precautions listed on the label of the boxes are entirely adequate but were not, apparently, adopted by most of the users in the settlement. The patient's complaints started after a delay of one or two days. There followed in sequence blurring of vision, giddiness, prolonged and broken sleep, xanthopsia, and a variety of hallucinations. On examination the patient was in a marked depressive state. There was a slight contraction of up to $20^{\circ}$ of the visual fields although the visual acuity and fundi were normal. The state of mental confusion and depression improved slowly. On December 24, 1963, 20 days after exposure, visual hallucinations had disappeared, the visual fields were normal, and the patient returned to his normal activities. It

'Present address: Research Laboratories, Emek Hajarden.

2‘Abic' Pharmaceutical Industries, Ramat-Gan.

Received for publication November 7, 1967. should be stressed, however, that his behaviour still remained somewhat slow.

The patient has since been re-examined and has completely recovered (last examined on July 20, 1967).

Special Investigations A routine blood count and urinalysis on December 12, 1963 were essentially normal; alkaline phosphatase 6.9 K.A. units, S.G.O.T. 6 units (local normal values up to 35 units), cholinesterase activity I.94 (normal local values $\mathrm{I} \cdot 8-3 \cdot 2)$, bilirubin in blood $0.5 \mathrm{mg}$. $/ \mathrm{r} 00 \mathrm{ml}$., cholesterol $190 \mathrm{mg}$./100 ml. (normal local values I70-240), blood urea $37 \mathrm{mg}$./100 ml. Toxicological findings were: trichloroacetic acid in urine $3 \mathrm{mg}$./1., inorganic sulphate in urine $0.56 \mathrm{~g} . / 1$. (decreased), ethereal fraction of sulphate $\mathrm{r} \cdot 59 \mathrm{~g} . / 1$. (increased), neutral sulphur in urine 0.12 g./1. (normal).

In the blood the following fractionation was found: inorganic sulphate 0.80 (normal); organic sulphate I.4I (increased); neutral sulphur 2.05 (normal). The normal local values of both blood and urine fractions, as well as their changes in the course of recovery of our patient, will be discussed in detail later.

An electroencephalogram (E.E.G.) performed on December I5 showed a normal tracing. It was, however, striking that the 9 -waves/sec. rhythm was disturbed by slow frequency waves of $4-6 / \mathrm{sec}$. in the posterior regions. Although non-specific, this is an additional indication of the state of drowsiness, especially when it is noted that the peculiarity mentioned did not reappear on an E.E.G. on April 19, 1964, five months after the poisoning. 


\section{Differential Diagnosis}

The variety of clinical manifestations in acute, subacute, and chronic carbon disulphide poisoning may simulate a number of diseases and intoxications (Browning, 1965; Nesswetha, 1956; Vigliani and Pernis, 1955; Grant, 1962; Savič, I967). A consideration of the differential diagnosis of the present case suggests the following five possibilities:

I. an early stage of severe mental disturbance with mental confusion as the presenting symptom;

2. a depressive state of reactive or endogenous aetiology;

3. trichloroethylene poisoning;

4. carbon tetrachloride poisoning;

5. carbon disulphide poisoning.

Poisoning by trichloroethylene or carbon tetrachloride is ruled out because of the unusual clinical picture which does not represent poisoning by either of these toxic hazards and because the excretion of the metabolite trichloroethylene was normal.

The phenomenon of transient disturbance of higher brain centres, the rapid disappearance of mental confusion, and the somewhat slow, but complete and lasting, recovery make the diagnosis of endogenous psychosis very improbable.

Furthermore, follow-up for four consecutive years, to the present, has revealed the patient to be completely normal mentally. In fact, the diagnosis of carbon disulphide intoxication is confirmed by both the case history and the environmental data. Laboratory investigations were of less diagnostic significance in this case, with the exception of the greatly increased ethereal sulphate which would seem to be directly connected with the poisoning.

\section{Sulphur Excretion in Urine}

The examination of successive urine samples in

TABLE

Changes in Excretion of Urinary SUlphates after POISONING BY CARBON DISULPHIDE

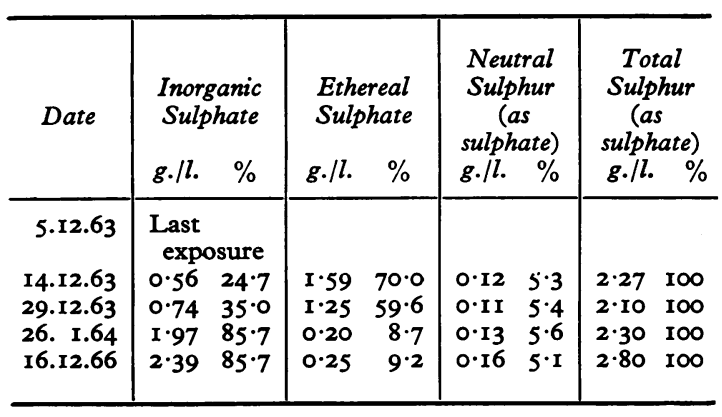

this case of carbon disulphide poisoning revealed a considerable increase in the ethereal fraction of sulphates. Equally striking was the fact that three weeks after the last exposure the findings were still definitely abnormal, although the patient had almost recovered clinically. The normal pattern of urinary sulphur excretion was probably reached only about six weeks after exposure (Table).

On December 14, 1963, one week after exposure, an analysis of sulphur in the serum was performed, providing further evidence of an increase in the formation of ethereal sulphate:

Normal Values

(Reed and

Denis, 1927)

Inorganic sulphates $0.8 \mathrm{mg} . / 100 \mathrm{ml} .0 .5-\mathrm{I} \cdot \mathrm{I} 2$

Ethereal sulphates $\mathrm{I} \cdot 4 \mathrm{I} \mathrm{mg} . / \mathrm{I} 00 \mathrm{ml} .0 .09-0.96$

Neutral sulphur $\quad 2.05 \mathrm{mg}$./100 ml. I.72-2.54

The different sulphate fractions were estimated by the method of Folin (1905), using 10\% barium chloride to precipitate sulphates before and after ethereal extraction of urine. The total sulphur content is obtained after oxidation of an additional sample of the same specimen.

\section{Comment}

It has been established that the relationship of approximately 8 to $\mathrm{I}$ between inorganic and organic urinary sulphates is reasonably maintained despite some changes with variation of the protein content of the diet. Only in cases of extremely low protein diet does the inorganic sulphate component drop as low as $60 \%$ of total (Wakefield, 1929; Power, Goudsmit, and Keith, 1940), and then the total sulphate excretion in urine decreases to less than $\mathrm{I} \cdot \mathrm{O}$ g./litre. Therefore, only gross increases in the formation of ethereal sulphate are of toxicological significance (Shiple, Muldoon, and Sherwin, 1924; Power et al., 1940).

Apart from the present case, an ethereal sulphate excretion of more than $50 \%$ of total urinary sulphate has been detected in eight additional cases in our region, all of them heavily exposed to the vapours of benzene or its derivates.

Further, a group of more than 70 industrial employees and laboratory technicians in contact with different solvents revealed a strictly normal pattern of urinary sulphate distribution. In all the normal and abnormal specimens which have been examined so far, the total sulphate excretion varied within the limits of $2.05 \mathrm{~g}$. $/ 1$. and $3.20 \mathrm{~g}$. $/ 1$.

It is obviously impossible to comment on the phenomenon of increased ethereal sulphate formation and excretion on one case of carbon disulphide poisoning. We feel, however, that this may be an 
important observation for further study of the fate of absorbed carbon disulphide. Strittmatter, Peters, and McKee (1950), Michalowá and Frýdl (1957), and Souček and Mādlo (1956) have made considerable contributions to the understanding of biotransformation of carbon disulphide in laboratory animals, the formation of dithiocarbamin carbonic acid being of particular interest (Souček and Mādlo, 1956). However, to our knowledge there has been no previous report of a clear-cut increased ethereal fraction of sulphates in man, in spite of extensive studies on carbon disulphide metabolism by McKee, Kiper, Fountain, Riskin, and Drinker (1943), Teisinger and Souček (1949), and Nesswetha (1956).

\section{REFERENCES}

Browning, Ethel (1965). Toxicity and Metabolism of Industrial Solvents. Ist ed., pp. 703-712. Elsevier, Amsterdam.

Folin, O. (1905). On sulphate and sulphur determinations. f. biol. Chem., 1, 131-159.

Grant, W. Morton (1962). Toxicology of the Eye, pp. 104-106. Ist ed. Thomas, Springfield, Illinois.

McKee, R. W., Kiper, C., Fountain, J. H., Riskin, A. M., and Drinker, P. (1943). A solvent vapor, carbon disulfide: absorption, elimination, metabolism and mode of action. F. Amer. med. Ass., 122, 217-222.

Michalowá, C., and Frýdl, Z. (1957). Veränderungen der höheren Nerventätigkeit und einiger humoraler
Faktoren nach parenteraler Intoxikation des Kaninchens mit Schwefelkohlenstoff. Arch. Gewerbepath. Gewerbehyg., 15, 553-564.

Nesswetha, W. (1956). Klinische Untersuchungen zur Pathophysiologie des Schwefelkohlenstoffes. Ibid., 14, 522-553.

Power, M. H., Goudsmit, A., and Keith, N. M. (1940). The excretion of sulfate by normal men. F. biol. Chem., 133, Suppl.: Proc. Amer. Soc. biol. Chem., 34th Ann. Meeting, lxxvii-lxxviii.

Reed, L., and Denis, W. (1927). On the distribution of the non-protein sulfur of the blood between serum and corpuscles. Ibid., 73, 623-626.

Savič, S. M. (1967). Influence of carbon disulphide on the eye. Arch. environm. Hlth, 14, 325-326.

Shiple, G. J., Muldoon, J. A., and Sherwin, C. P. (1924). The formation of ethereal sulphates. F. biol. Chem., 60, 59-67.

Souček, B., and Mādlo, Z. (1956). Dithiocarbamincarbon Säuren als Abbauprodukte des Schwefelkohlenstoffs. Arch. Gewerbepath Gewerbehyg., 14, 5 I I-52I.

Strittmatter, C. F., Peters, T., and McKee, R. W. (1950). Metabolism of labeled carbon disulphide in guinea pig and mice. Arch. industr. Hyg., 1, 54-64.

Teisinger, J., and Souček, B. (1949). Absorption and elimination of carbon disulphide in man. $\mathcal{F}$. industr. Hyg., 31, 67-74.

Vigliani, E. C., and Pernis, B. (1955). Klinische und experimentelle Untersuchungen über die durch Schwefelkohlenstoff bedingte Atherosklerose. Arch. Gewerbepath. Gewerbehyg., I4, 190-202.

Wakefield, E. G. (1929). The colorimetric determination of total and inorganic sulphates in blood serum, urine, and other body fluids. F. biol. Chem., 81, 713-721. 